\title{
A Prodrug of NMDA/Glycine Site Antagonist, L-703,717, with Improved BBB Permeability: 4-Acetoxy Derivative and Its Positron-Emitter Labeled Analog
}

\author{
Terushi HaradahiRa, ${ }^{*}, a$ Ming-Rong Zhang, ${ }^{b}$ Jun Maeda, ${ }^{b}$ Takashi OKauchi, ${ }^{b}$ Takayo KIda, ${ }^{b}$ \\ Kouichi Kawabe, ${ }^{c}$ Sigeki Sasaki, ${ }^{d}$ Tetsuya SuHARA, ${ }^{a, b}$ and Kazutoshi SuzukI ${ }^{a}$ \\ Division of Advanced Technology for Medical Imaging, National Institute of Radiological Sciences, ${ }^{a}$ Chiba 263-8555, \\ Japan, SHI Accelerator Service, ${ }^{b}$ Tokyo 141-8686, Japan, Core Research for Evolution Science and Technology, Japan \\ Science and Technology Corporation, ${ }^{c}$ Kawaguchi, Saitama 332-0012, Japan, and Faculty of Pharmaceutical Sciences, \\ Kyushu University, ${ }^{d}$ Fukuoka 812-8582, Japan. Received July 26, 2000; accepted December 5, 2000
}

\begin{abstract}
4-Acetoxy derivative (1) of $\mathrm{L}-703,717$, a high-affinity $\left(\mathrm{IC}_{50}=4.5 \mathrm{nM}\right)$ antagonist for the glycine site of NMDA receptors, was synthesized and its brain uptake was examined using a carbon-11 labeled analog $\left.\left({ }^{11} \mathrm{C}\right] 1\right)$. Initial radioactivity in the brain after intravenous injection of $\left[{ }^{11} \mathrm{C}\right] 1$ was a 2 -fold that of $\left[{ }^{11} \mathrm{C}\right] \mathrm{L}-703,717$ in mice. Rapid bioconversion of $\left[{ }^{11} \mathrm{C}\right] 1$ into $\left[{ }^{11} \mathrm{C}\right] \mathrm{L}-703,717$ was demonstrated by metabolite analyses of rat brain after $\left[{ }^{11} \mathrm{C}\right] 1$ injection. Ex vivo autoradiography of $\left[{ }^{11} \mathrm{C}\right] 1$ in rat brain showed the same cerebellar localization of radioactivity as $\left[{ }^{11} \mathrm{C}\right] \mathrm{L}-703,717$. These results indicate that 1 is a promising pharmacological tool as a prodrug of $\mathrm{L}-703,717$ with improved BBB permeability.
\end{abstract}

Key words prodrug; L-703,717; NMDA glycine site; PET ligand

$N$-Methyl-D-aspartate (NMDA) receptors play an important role in brain development and plastic synaptic events such as memory formation and learning. Overactivation of this receptor is implicated in a variety of neurological diseases such as ischemia during stroke and trauma, Parkinson's and Huntington's diseases, schizophrenia, and epilepsy. Therefore, compounds acting as NMDA antagonists are potentially useful not only for treatment of such diseases but for functional studies of NMDA receptors in central nervous system (CNS). Of various regulatory sites on NMDA receptors, a glycine-binding site has become of considerable interest as a therapeutic target for correcting glutamatergic dysfunctions. ${ }^{1,2)}$ The glycine site antagonists may have reduced side-effect liability compared with antagonists acting at other sites on the NMDA receptors. Therefore a variety of structural classes of antagonists for this site have been developed to date. ${ }^{1-3)}$ The majority of these antagonists, however, have poor physicochemical properties for adequately penetrating the blood-brain barrier (BBB). Therefore, the issues of achieving good BBB permeability with glycine site antagonists remains largely unresolved.

4-Hydroxyquinolones such as L-701,324 and L-703,717 are one of the most potent and orally active antagonists for the glycine-binding site yet described, ${ }^{4)}$ but unfortunately these are poorly taken up by the brain because they bind tightly to albumin in plasma. ${ }^{5)}$ Rowley and co-workers have shown that the binding of L-701,324 to albumin can be effectively inhibited by pre-treatment with warfarin, a drug that resembles L-701,324 in structure and probably competes with L-701,324 for albumin binding. ${ }^{5}$ ) We have recently shown that simultaneous injection of warfarin dose-dependently increases the brain uptake of a positron-emitter labeled L-703,717 ([ $\left.\left.{ }^{11} \mathrm{C}\right] \mathrm{L}-703,717\right)$ in mice. ${ }^{6)}$ It was further found that, after the increase in brain uptake by warfarin, the glycine site antagonist was more highly localized in the rodent cerebellum than in regions with high-density NMDA glycine receptors. ${ }^{6}$ This unusual localization in vivo has been strongly suggested to be due to preferential binding to
NR1/NR2C subunits of the NMDA receptors that is only expressed in the adult cerebellum. ${ }^{7,8)}$ Thus, L-703,717 and its positron-emitter labeled analog may be useful pharmacological tools with which to address the physiological and pathological roles of the glycine site consisting of the NR2C subunit in the cerebellum.

An alternative method of overcoming the poor BBB permeability of a drug is chemical modification of the drug to form a new compound known as a prodrug, which upon in vivo enzymatic attack will liberate the parent compound. The 4-hydroxyquinolones are all acidic with $\mathrm{p} K_{\mathrm{a}}$ values of around 5 or below, and therefore largely ionized at physiological $\mathrm{pH}$. The ionization of a drug in blood usually reduces its ability to penetrate the $\mathrm{BBB}$, and the acidic compounds are more amenable to bind with albumin than non-acidic compounds. ${ }^{5)}$ Therefore protection of the ionizable hydroxyl groups of the 4-hydroxyquinolones by esters might prevent their ionization in vivo and eventually alter their binding characteristic to serum albumin, leading to the enhancement of brain penetration by the 4-hydroxyquinolones. The esters taken up by the brain can be expected to be hydrolyzed to L-703,717 by ubiquitous esterase in the brain. Based on these predictions, we have synthesized a 4-acetoxy derivative (1) of L-703,717 and evaluated its potential as a prodrug of L-703,717 for improved BBB permeability by employing a carbon-11 labeled analog $\left(\left[{ }^{11} \mathrm{C}\right] \mathbf{1}\right)$.

\section{Results and Discussion}

Acetylation of L-703,717 was easily accomplished by treatment with acetic anhydride and 2,6-lutidine in THF at $80{ }^{\circ} \mathrm{C}$ for $1 \mathrm{~h}$, and gave 1 in an $79 \%$ yield after purification by column chromatography. The chemical structure of 1 was unambiguously identified by both $\mathrm{H}-\mathrm{H}$ COSY and NOESY spectral analyses, in which a typical proton signal corresponding to the amide group of $\mathbf{1}$ was appeared at $12.15 \mathrm{ppm}$, indicating no formations of either $N$-acetyl or 2-acetoxy compound. A positron-emitter labeled $\left[{ }^{11} \mathrm{C}\right] \mathbf{1}$ was obtained by the methylation of a precursor $(2)$ with $\left[{ }^{11} \mathrm{C}_{3} \mathrm{CH}_{3} \mathrm{I}\right.$ as de- 


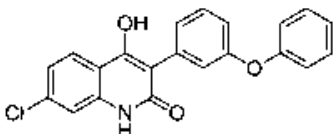

L-701,324

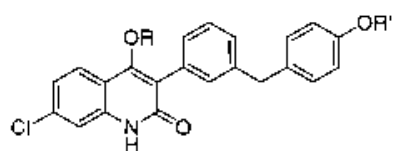

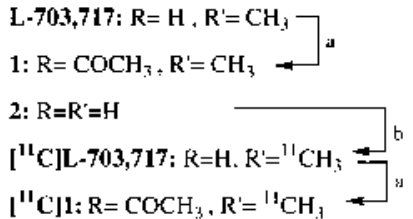

Fig. 1. Chemical Structures of 4-Hydroxyquinolones and Preparation of 4-Acetoxy Derivatives

(a) $\mathrm{Ac}_{2} \mathrm{O} / 2$,6-lutidine/THF, $80^{\circ} \mathrm{C}$. (b) $\left[{ }^{11} \mathrm{C}\right] \mathrm{CH}_{3} \mathrm{I}, \mathrm{NaH}, \mathrm{DMF}, 30^{\circ} \mathrm{C}$.

Table 1. Brain Penetration of $\left[{ }^{11} \mathrm{C}\right] \mathbf{1}$ and $\left[{ }^{11} \mathrm{C}\right] \mathrm{L}-703,717$ in Mice ${ }^{a)}$

\begin{tabular}{lrrrr}
\hline \hline & & \multicolumn{3}{c}{$\%$ dose $/ \mathrm{g}^{b)}$} \\
\cline { 3 - 5 } Compound & $\begin{array}{c}\text { Warfarin } \\
(\mathrm{mg} / \mathrm{kg})\end{array}$ & Cerebellum & Cerebrum & Blood \\
\cline { 3 - 5 } & & & & \\
\hline$\left[{ }^{11} \mathrm{C}\right] \mathbf{1}$ & 0 & $0.71 \pm 0.10$ & $0.58 \pm 0.05$ & $8.24 \pm 1.39$ \\
{$\left[{ }^{11} \mathrm{C}\right] \mathbf{1}$} & 00 & $1.71 \pm 0.14$ & $1.49 \pm 0.07$ & $7.98 \pm 0.47$ \\
{$\left[{ }^{11} \mathrm{C}\right] \mathrm{L}-703,717^{c)}$} & 0 & $0.36 \pm 0.05$ & $0.32 \pm 0.03$ & $8.37 \pm 0.60$ \\
{$\left[{ }^{11} \mathrm{C}\right] \mathrm{L}-703,717^{c)}$} & 100 & $1.37 \pm 0.21$ & $1.28 \pm 0.20$ & $7.54 \pm 0.79$
\end{tabular}

a) $\left[{ }^{11} \mathrm{C}\right] 1$ or $\left[{ }^{11} \mathrm{C}\right] \mathrm{L}-703,717$ was injected intravenously to ddY mice $(8-10$ weeks old) together with or without warfarin. After 1 min post injection, the radioactivity in the cerebrum, cerebellum, and blood were measured as described in the literature. ${ }^{6}$ b) Average of $4-6$ mice \pm S.D. c) Data from ref. 6.

scribed in the literature ${ }^{9)}$ and subsequent acetylation with the acetic anhydride and 2,6-lutidine by the same procedure as for the preparation of non-radioactive 1 (Fig. 1). After HPLC purification, radiochemically pure $(>99 \%)\left[{ }^{11} \mathrm{C}\right] 1$ was obtained as an isotonic saline solution. The chemical identity of $\left[{ }^{11} \mathrm{C}\right] 1$ was accomplished by HPLC comparisons with authentic 1 using two different kinds of reversed-phase analytical columns. The synthesis time was about 33 min from the end of proton bombardment. The specific activity of $\left[{ }^{11} \mathrm{C}\right] \mathbf{1}$ was $51-73 \mathrm{GBq} / \mu \mathrm{mol}$ at the end of synthesis.

Initial radioactivity (\% administered dose/g of tissue) in mouse brain at $1 \mathrm{~min}$ after intravenous injection of $\left[{ }^{11} \mathrm{C}\right] \mathbf{1}$ was 2-fold that of $\left[{ }^{11} \mathrm{C}\right] \mathrm{L}-703,717$ as shown in Table 1. Coinjection of $\left[{ }^{11} \mathrm{C}\right] 1$ with $100 \mathrm{mg} / \mathrm{kg}$ warfarin further increased the initial radioactivity in the brain by a factor of 2.5 , suggestive of competitive binding of $\mathbf{1}$ to plasma albumin, similarly to L-703,717. However, the fact that the ester was rapidly hydrolyzed to $\left[{ }^{11} \mathrm{C}\right] \mathrm{L}-703,717$, with a half-life of less than $10 \mathrm{sec}$, in mouse and rat plasma made it difficult to assess the effect of warfarin on the brain uptake of intact $\left[{ }^{11} \mathrm{C}\right] \mathbf{1}$, and hence to understand the alteration of the binding characteristic of L-703,717 to albumin by introducing the ester group into the 4-position. The increase in lipophilicity $(\log \mathrm{P}=3.9$ for $\left.\left[{ }^{11} \mathrm{C}\right] \mathbf{1}\right)$ might not be responsible for the increase in the brain uptake of $\left[{ }^{11} \mathrm{C}\right] \mathbf{1}$ because $\left[{ }^{11} \mathrm{C}\right] \mathrm{L}-703,717$ was also lipophilic $(\log \mathrm{P}=3.0)$ enough to penetrate the BBB. Further studies will be required to obtain the direct evidence as to whether the increase in the brain radioactivity after intravenous injection of $\left[{ }^{11} \mathrm{C}\right] \mathbf{1}$ was due to the reduced protein binding of $\left[{ }^{11} \mathrm{C}\right] 1$ or to other factors. The present study, however, indicates that chemical modification at the 4-position may be an effective way of enhancing brain penetration by 4hydroxyquinolones. Two-fold increase of radioactivity in the brain after $\left[{ }^{11} \mathrm{C}\right] \mathbf{1}$ injections compared to $\left[{ }^{11} \mathrm{C}\right] \mathrm{L}-703,717$

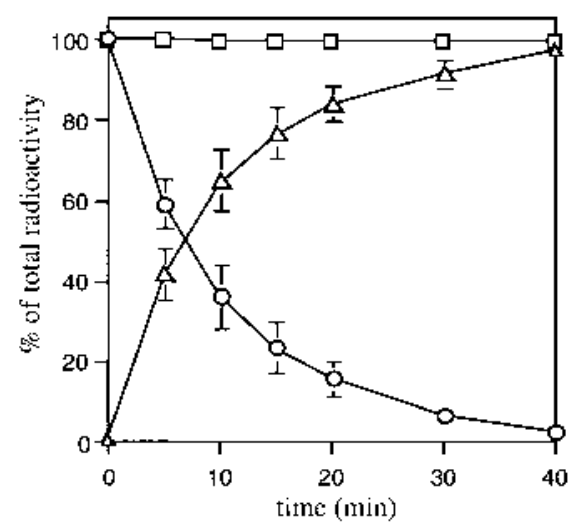

Fig. 2. Percent Conversion of $\left[{ }^{11} \mathrm{C}\right] \mathbf{1}$ into $\left[{ }^{11} \mathrm{C}\right] \mathrm{L}-703,717$ in Rat Brain Homogenates in Phosphate Buffer

$\left[{ }^{11} \mathrm{C}\right] \mathbf{1}$ in homogenate $(O)$; $\left[{ }^{11} \mathrm{C}\right] \mathrm{L}-703,717$ in homogenates $(\triangle) ;\left[{ }^{11} \mathrm{C}\right] \mathbf{1}$ in buffer $(\square)$. The values are means of three separate experiments.

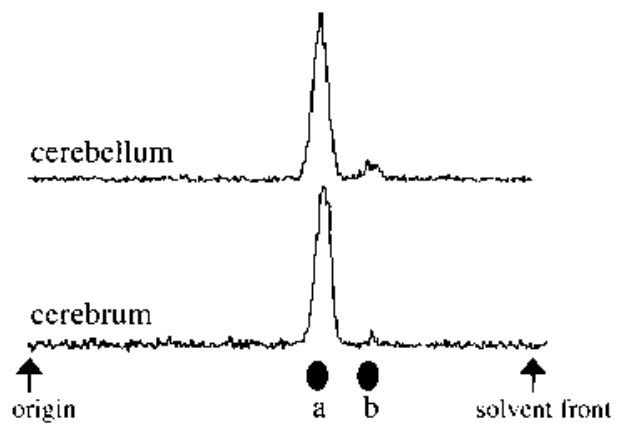

Fig. 3. Typical Radio-TLCs of Metabolites in $\mathrm{MeOH}$ Extracts from Rat Cerebellum and Crebrum Obtained at $5 \mathrm{~min}$ after Injection of $\left[{ }^{11} \mathrm{C}\right] \mathbf{1}$

Authentic L-703,717 (a) and 1 (b).

were also observed by both rat and monkey brain (data not shown), indicating no species difference in the brain uptake characteristic of $\left[{ }^{11} \mathrm{C}\right] \mathbf{1}$.

Metabolism of $\left[{ }^{11} \mathrm{C}\right] \mathbf{1}$ was examined in rat brain homogenates diluted in a phosphate buffer (Fig. 2) as well as in intact rat brain (Fig. 3) by using radio-TLC technique. The ester underwent metabolism in the homogenates and, at 20 min after incubation, about $80 \%$ of $\left[{ }^{11} \mathrm{C}\right] 1$ was converted to $\left[{ }^{11} \mathrm{C}\right] \mathrm{L}-703,717$ as shown in Fig. $2 .\left[{ }^{11} \mathrm{C}\right] \mathbf{1}$ was quite stable in the buffer alone under the experimental conditions used, and there were no metabolites other than $\left[{ }^{11} \mathrm{C}\right] \mathrm{L}-703,717$ detected in the homogenates by radio-TLC and HPLC analyses. Rapid bioconversion of $\left[{ }^{11} \mathrm{C}\right] \mathbf{1}$ into $\left[{ }^{11} \mathrm{C}\right] \mathrm{L}-703,717$ in intact rat brain was demonstrated by the radio-TLC analyses of the metabolites in $\mathrm{MeOH}$ extract from the rat brain at $5 \mathrm{~min}$ after $\left[{ }^{11} \mathrm{C}\right] 1$ injection, in which greater than $90 \%$ of the total radioactivity in $\mathrm{MeOH}$ was assigned to be $\left[{ }^{11} \mathrm{C}\right] \mathrm{L}-703,717$. As shown in Fig. 4, ex vivo brain autoradiography obtained at $20 \mathrm{~min}$ after intravenous $\left[{ }^{11} \mathrm{C}\right] \mathbf{1}$ injection showed the same cerebellar specific localization of radioactivity as observed for $\left[{ }^{11} \mathrm{C}\right] \mathrm{L}-703,717^{6}$ ). This cerebellar localization disappeared by co-injection of a large amount $(1 \mathrm{mg} / \mathrm{kg})$ of non-radioactive L-703,717, further supporting the prodrug characteristic of 1 .

In conclusion, the present works indicate that $\mathbf{1}$ is a prodrug of an NMDA/glycine site antagonist L-703,717, showing increased BBB permeability. Our previous study using 


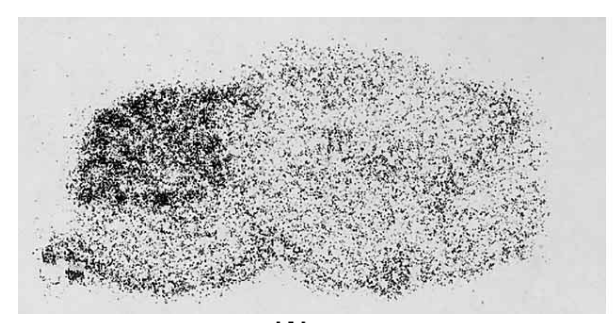

(A)

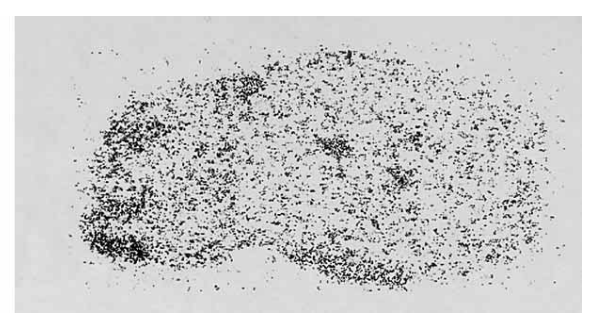

(B)

Fig. 4. Autoradiographic Images of Rat Brain Sagittal Sections Obtained at $20 \mathrm{~min}$ after Injection of $\left[{ }^{11} \mathrm{C}\right] \mathbf{1}(\mathrm{A})$ or together with L-703,717 (1 mg/kg) and Warfarin $(60 \mathrm{mg} / \mathrm{kg})(B)$

The images were obtained by exposing the sections for $60 \mathrm{~min}$ to imaging plates and subsequent analyses of the plates with a BAS 3000 bioimaging analyzer.

NR2C subunit deficient mice has demonstrated that L703,717 preferentially binds with cerebellar NMDA receptors consisting of NR2C subunit in vivo. ${ }^{7}$ Thus it would be very interesting to further evaluate the in vivo potency of $\mathbf{1}$ for therapeutic use in place of the NMDA subunit-selective antagonist, L-703,717. Furthermore, the positron-emitter labeled $\left[{ }^{11} \mathrm{C}\right] 1$ may be a useful radioligand with which to address the physiological and pathological roles of the cerebellar glycine site in living brain, in conjunction with positron emission tomography (PET). Despite this progress, continuing efforts to design a prodrug having a higher BBB permeability than $\mathbf{1}$ are currently underway.

\section{Experimental}

Melting point $(\mathrm{mp})$ is uncorrected. Nuclear magnetic resonance $\left({ }^{1} \mathrm{H}\right.$ NMR) spectrum was recorded on a Varian Unity 500 spectrometer with tetramethylsilane as an internal standard. All chemical shifts $(\delta)$ are reported in parts per million (ppm) down field from the standard. High-resolution fast atom bombardment mass spectrum (HRFAB-MS) was obtained on a JEOL NMS-SX102 spectrometer. Column chromatography was done on Merck Kieselgel $60 \mathrm{~F}_{254}(70-230 \mathrm{mesh})$. Thin layer chromatography (TLC) was carried out on Merck Kieselgel $60 \mathrm{~F}_{254}$ plates. Radioactivity was quantified with a IGC-3R Curiemeter (Aloka). High-pressure liquid chromatography (HPLC) was done using a JASCO HPLC system for radioactive runs. Effluent radioactivity from the HPLC was determined using a $\mathrm{NaI}(\mathrm{Tl})$ scintillation detector system. Carbon-11 was generated by the ${ }^{14} \mathrm{~N}(\mathrm{p}, \alpha){ }^{11} \mathrm{C}$ nuclear reaction using a CYPRIS HM-18 cyclotron (Sumitomo Heavy Industries, Ltd.). Preparation of $\left[{ }^{11} \mathrm{C}_{\mathrm{CH}_{3} \mathrm{I}}\right.$ and subsequent ${ }^{11} \mathrm{C}$-methylations were carried out automatically by using a synthetic apparatus for ${ }^{11} \mathrm{C}$-labeled compounds developed by Suzuki et al. ${ }^{10)} \log \mathrm{P}$ values of radioligands were determined by a conventional measurements of the partition coefficient $(\mathrm{P})$ between $n$-octanol and $0.1 \mathrm{~m}$ phosphate buffer $(\mathrm{pH}=7.4)$ at ambient temperature.

4-Acetoxy-7-chloro-3-[3-(4-methoxybenzyl)phenyl]-2(1H)-quinolone (1) $\mathrm{L}-703,717(43.2 \mathrm{mg}, 110.2 \mu \mathrm{mol})$ was added to a solution of acetic anhydride/2,6-lutidine in THF ( $5 \mathrm{ml}$, Wako Chemical, Osaka, Japan ) and the mixture was stirred at $80^{\circ} \mathrm{C}$ for $1 \mathrm{~h}$. After removal of the solvents, the residue was dissolved in $\mathrm{CHCl}_{3}$, which was washed with cold $1 \mathrm{~N} \mathrm{HCl}$, saturated $\mathrm{NaCl}$, dried over $\mathrm{Na}_{2} \mathrm{SO}_{4}$, and evaporated to dryness under reduced pressure. The crude product obtained was purified by column chromatography on silica gel with dichloromethane/ethyl acetate $(9 / 1)$ to give pure $\mathbf{1}$ $(37.8 \mathrm{mg}, 79 \%)$ as a white solid. $\mathrm{mp} 168-170^{\circ} \mathrm{C}$ (from methanol); ${ }^{1} \mathrm{H}$ NMR $\left(d_{6}\right.$-DMSO $\delta: 1.97(3 \mathrm{H}, \mathrm{s}), 3.70(3 \mathrm{H}, \mathrm{s}), 3.89(2 \mathrm{H}, \mathrm{s}), 6.85(2 \mathrm{H}, \mathrm{d}$, $J=8.5 \mathrm{~Hz}), 7.11(1 \mathrm{H}, \mathrm{bs}), 7.12(1 \mathrm{H}, \mathrm{d}, J=6.0 \mathrm{~Hz}), 7.14(2 \mathrm{H}, \mathrm{d}, J=8.5 \mathrm{~Hz})$, $7.22(1 \mathrm{H}, \mathrm{d}, J=6.0 \mathrm{~Hz}), 7.23(1 \mathrm{H}, \mathrm{dd}, J=6.0,2.1 \mathrm{~Hz}), 7.34(1 \mathrm{H}, \mathrm{t}, J=6.0 \mathrm{~Hz})$, $7.41(1 \mathrm{H}, \mathrm{d}, J=2.1 \mathrm{~Hz}), 7.64(1 \mathrm{H}, \mathrm{d}, J=8.0 \mathrm{~Hz}), 12.15(1 \mathrm{H}, \mathrm{s})$. HRFAB-MS Calcd for $\mathrm{C}_{25} \mathrm{H}_{21} \mathrm{NO}_{4} \mathrm{NCl}(\mathrm{M}+\mathrm{H})$ : 434.1159. Found: 434.1205.

Radiosynthesis of $\left[{ }^{11} \mathbf{C}\right] \mathbf{1}$ After the methylation of a precursor (2) with $\left[{ }^{11} \mathrm{C}_{\mathrm{CH}_{3} \mathrm{I}}\right.$ in dry DMF reported in the literature, ${ }^{9)}$ acetic anhydride/2,6-lutidne in THF (Wako Pure Chemical, Osaka, Japan, $200 \mu$ l) was introduced in the DMF solution and heated at $80^{\circ} \mathrm{C}$ for $3 \mathrm{~min}$. The reaction mixture was transferred onto a HPLC column (JASCO MegaPak SIL C18, $250 \times 10 \mathrm{~mm}$ ) and eluted with $\mathrm{CH}_{3} \mathrm{CN} / \mathrm{H}_{2} \mathrm{O}(50 / 50)$ at a flow rate of $7 \mathrm{ml} / \mathrm{min}$. A radioactive fraction having a retention time $\left(t_{\mathrm{R}}\right)$ of $11.5 \mathrm{~min}$ was collected in a flask containing Tween-80 $(75 \mu \mathrm{l})$ and EtOH $(150 \mu \mathrm{l})$, concentrated to dryness under reduced pressure in a rotary evaporator, and the residue was dissolved in isotonic saline $(5-10 \mathrm{ml})$. By this procedure, $0.80-0.96 \mathrm{GBq}$ of $\left[{ }^{11} \mathrm{C}\right] \mathbf{1}$ was obtained as an isotonic saline solution in a total synthesis time of $33 \mathrm{~min}$ after a 20 min proton bombardment at a beam current of $15 \mu \mathrm{A}$. The $\left[{ }^{11} \mathrm{C}\right] \mathbf{1}$ obtained after the formulation was identified by HPLC comparison with authentic 1 using two different kinds of reversed-phase analytical columns. $t_{\mathrm{R}}$ was $7.2 \mathrm{~min}$ for a JASCO FinePak SIL C18 column $\left(\mathrm{CH}_{3} \mathrm{CN} / \mathrm{H}_{2} \mathrm{O}=60 / 40\right.$, $1.5 \mathrm{ml} / \mathrm{min})$ and $6.5 \mathrm{~min}$ for a Waters $\mu$-Bondapak $\mathrm{C} 18$ column $(\mathrm{MeOH} /$ $0.07 \mathrm{M}$ ammonium formate $=80 / 20,1 \mathrm{ml} / \mathrm{min}$ ). The specific activity and radiochemical purity of $\left[{ }^{11} \mathrm{C}\right] \mathbf{1}$ was $51-73 \mathrm{GBq} / \mu \mathrm{mol}$ and $>99 \%$, respectively, at the end of synthesis.

Mouse Brain Uptake of $\left[{ }^{11} \mathbf{C}\right] 1 \quad\left[{ }^{11} \mathrm{C}\right] \mathbf{1}(0.2 \mathrm{ml}, \mathrm{ca} .37 \mathrm{MBq} / \mathrm{ml})$ was injected intravenously via a tail vein to ddY mice ( $8-9$ weeks old) together with or without warfarin $(100 \mathrm{mg} / \mathrm{kg})$. The animals were killed by decapitation at $1 \mathrm{~min}$ after the injection. The brain was rapidly removed, dissected into cerebrum and cerebellum, and weighed. Radioactivities in the tissues were measured with a Packard autogamma scintillation counter and corrected for decay. The results are expressed as the percent administered dose per gram of tissue (\% dose $/ \mathrm{g})$ (Table 1$)$.

In Vitro Metabolism of $\left[{ }^{11} \mathbf{C}\right] 1$ The whole brain of male Sprague-Dawley rat $(450 \mathrm{~g})$ was removed and immediately homogenized in a 10-times volume of ice-cold $0.1 \mathrm{~m}$ phosphate buffer $(\mathrm{pH}=7.4)$ using a glass-Teflone homogenizer and stored rapidly at $-80^{\circ} \mathrm{C}$ until use. To the homogenates $(0.9 \mathrm{ml})$ pre-incubated at $37^{\circ} \mathrm{C}$ for $10 \mathrm{~min},\left[{ }^{11} \mathrm{C}\right] \mathbf{1}(0.1 \mathrm{ml}, c a .3-4 \mathrm{MBq})$ was added and incubated at the same temperature with gentle shaking. At appropriate time points, a $100 \mu$ l volume of the homogenate was removed and added to ice-cold $2 \mathrm{~N}-\mathrm{HCl}(50 \mu \mathrm{l})$ to terminate the enzyme reaction. About $2-3 \mu$ of the solution was spotted on a silica gel TLC plate, which was then developed with $\mathrm{CHCl}_{3} / \mathrm{CH}_{3} \mathrm{CN}(2: 1)$ as a mobile phase. The TLC plate was placed in contact with a phosphor imaging plate (BAS-SR 127, Fujiphoto Film Co., Ltd., Tokyo, Japan) for $30 \mathrm{~min}$, and the radioactivity distribution on the plate was analyzed by a FUJIX BAS 3000 bioimaging analyzer (Fujiphoto Film Co., Ltd.). The percent ratio of $\left[{ }^{11} \mathrm{C}\right] \mathbf{1}(R f=0.7)$ or $\left[{ }^{11} \mathrm{C}\right] \mathrm{L}-703,717(R f=0.6)$ to the total radioactivity on the plate was calculated as $\%=($ peak area for each compound/total peak area $) \times 100$, and the time-course of the ratios are shown in Fig. 2.

In Vivo Metabolism of $\left[{ }^{11} \mathbf{C}\right] \mathbf{1}$ At $5 \mathrm{~min}$ after intravenous injection of $\left[{ }^{11} \mathrm{C}\right] 1$ ( ca. $\left.150 \mathrm{MBq}\right)$ via a tail vein to male Sprague-Dawley rat, the rat was killed under ether anesthesia and the cerebellum and cerebrum were quickly removed. The tissues were homogenized with ice-cooled $\mathrm{MeOH}(2 \mathrm{ml})$ and centrifuged at $10000 \mathrm{rpm}$ for $1 \mathrm{~min}$ at $4{ }^{\circ} \mathrm{C}$. By this procedure, $86-92 \%$ of the total radioactivity in the tissues was extracted into $\mathrm{MeOH}$ supernatant. The metabolites in the $\mathrm{MeOH}$ were analyzed by the same method using TLC as described above.

Ex Vivo Autoradiography $\left[{ }^{11} \mathrm{C}\right] \mathbf{1}(110 \mathrm{MBq} / 0.5 \mathrm{ml})$ was injected intravenously via a tail vein to male Sprague-Dawley rat $(450 \mathrm{~g})$. After $20 \mathrm{~min}$, the rat was killed under ether anesthesia, and the brain was quickly removed, frozen in dry ice, and cut into sagittal sections $(20 \mu \mathrm{m})$ on a cryostat microtome (MICROM HM560, GmbH, Germany). These sections were thawmounted on a micro-cover glass (Matsunami Glass Ind., Ltd., Tokyo, Japan), dried on a hot plate $\left(50-60^{\circ} \mathrm{C}\right)$, and exposed for $60 \mathrm{~min}$ to imaging. The distribution of radioactivity accumulated in the imaging plates was assessed by the FUJIX BAS 3000 bioimaging analyzer and visualized as shown in Fig. 4A. For determining the non-specific binding (Fig. 4B), $\left[{ }^{11} \mathrm{C}\right] \mathbf{1}$ was injected together with non-radioactive L-703,717 $(1 \mathrm{mg} / \mathrm{kg})$ and warfarin $(60 \mathrm{mg} / \mathrm{kg})$.

Acknowledgements The authors are grateful to Mr. T. Henmi and M. 
Mutoh of the Tokyo Nuclear Service, and to Mr. N. Nengaki of the SHI Accelerator Service, for their support in ${ }^{11} \mathrm{C}$-methylation. We thank the cyclotron crew of the National Institute of Radiological Sciences for technical support in radioisotope production.

\section{References}

1) Leeson P. D., Iversen L. L., J. Med. Chem., 37, $4053-4067$ (1994).

2) Danysz W., Parsons C. G., Pharmacol. Rev., 50, 597-664 (1998).

3) Kulagowski J. J., Exp. Opin. Ther. Patents, 6, 1069-1079 (1996).

4) Kulagowski J. J., Baker R., Curtis N. R., Leeson P. D., Mawer I. M., Moseley A. M., Ridgill M. P., Rowley M., Stansfield I., Foster A. C., Grimwood S., Hill R. G., Kemp J. A., Marshall G. R., Saywell K. L., Tricklebank M. D., J. Med. Chem., 37, 1402-1405 (1994).
5) Rowley M., Kulagowski J. J., Watt A. P., Rathbone D., Stevenson G. I., Carling R. W., Baker R., Marshall G. R., Kemp J. A., Foster A. C., Grimwood S., Hargreaves R., Hurley C., Saywell K. L., Tricklebank M. D., Leeson P. D., J. Med. Chem., 40, 4053- 4068 (1997).

6) Haradahira T., Zhang M.-R., Maeda J., Okauchi T., Kawabe K., Kida T., Suzuki K., Suhara T., Nucl. Med. Biol., 27, 357-360 (2000).

7) Haradahira T., Suhara T., Maeda J., Zhang M.-R., Okauchi T., Kawabe K., Suzuki K., Mishina M., Jpn. J. Pharmacol., 82, 455 (2000).

8) Mori H., Mishina M., Neuropharmacology, 34, 1219-1237 (1995).

9) Haradahira T., Suzuki K., Nucl. Med. Biol., 26, 245-247 (1999).

10) Suzuki K., Inoue O., Hashimoto K., Yamasaki T., Kuchiki M., Tamate K., Appl. Radiat. Isot., 36, 971 -976 (1985). 